\title{
Corporate Governance and Banking Stability: The Case of Universal Banks in Ghana
}

Submitted 02/03/20, $1^{\text {st }}$ revision 13/04/19, $2^{\text {nd }}$ revision 20/05/19, accepted 30/07/20
Kaodui $\mathrm{Li}^{11,2 *}$ Yusheng Kong ${ }^{1}$, Sampson Agyapong Atuahene ${ }^{2 *}$,
Geoffrey Bentum-Micah ${ }^{3}$, Michael Kwakye Agyapong ${ }^{4}$

Abstract:

Purpose: Many countries both develop and developing have issues concerning corporate governance mechanisms, policy and implementations and there needs to be addressed by researchers and academics. Our study seeks to investigate whether bank stability and corporate governance variables have a robust linkage.

Methodology: A country sampling of 23 commercial banks' data from 2008-2019 was used for our analysis. We employed a fixed effect estimator and generalized method of moments (GMM) estimation.

Findings: Using the fixed-effect approach, we declare that board size, ages of board members, the financial experience of board members, and CEO duality have a strong positive effect on bank stability measures. We find evidence these corporate governance variables help decrease bank's risk/insolvency. Next, we found out that, percentage of female directors, audit committee activities, and directors' educational composition/qualification have reversed rather than encouraged risk in banks. For the generalized method of moments setting, we discovered that board size has a mixed effect on banks' stability. The audit committee has a negative effect on banks' stability for only the tier 1 capital. Educational qualification and directors' compensation is negatively related to the bank's credit risk measure only. The ages' of directors (average age) is strongly related to the bank's stability measures. However, the percentage of independent directors' on the board is linked to Zscore only, while the financial experience of directors and the percentage of female directors are connected to credit risk measure only while CEO duality has a great linkage with both credit risk and tier 1 capital.

Practical Implications: The result indicates that banks still need to strengthen their corporate governance structures, which will help them stay strong and solvent. Originality/Value: This is crucial in understanding how governance works at the banks level and how it help in preventing financial instability.

Keywords: Corporate Governance, financial stability, generalized method of moments, Fixed-effects model.

${ }^{1}$ College of Economics and Management, Nanjing University of Aeronautics and Astronautics, Jiangsu Province, P.R. China, corresponding author

${ }^{2}$ School of Finance and Economics, Jiangsu University, Jiangsu Province, P.R. China, e-mail: 5103181207@stmail.ujs.edu.cn corresponding author

${ }^{3}$ School of Finance and Economics, Jiangsu University, Jiangsu Province, P.R. China,

${ }^{4}$ School of Finance and Economics, Jiangsu University, Jiangsu Province, P.R. China

${ }^{5}$ School of Management, Jiangsu University, Jiangsu Province, P.R. China

${ }^{6}$ Kwame Nkrumah University of Science and Technology, Ghana 
JEL codes: G01, G21, G34.

Paper type: Research article.

\section{Funding:}

The authors acknowledge the financial support of the National Nature Science Foundation of China (No. 71973054)-Project Title: Study on the Evolution and Optimization of Rural Governance System with the Dualistic Change of "Regulation-Culture".

\section{Introduction}

A possible reoccurrence of the financial crisis on a national and international basis has made both academics and practitioners to be attentiveness of corporate governance issues because they believe that corporate governance is the fulcrum around which organizations rotate (Lo, 2012). Contrarywise, some academics believe that corporate governance directives motivate businesses to form and take disproportionate risks for short-term profit maximization, instead of addressing asymmetric information matters, controlling managerial opportunism, and redirecting management toward optimal behavior (Akindele and Hassan, 2012; Aguilera and Cuervo-Cazurra, 2009; Kourtis et al., 2019; 2017).

Banking administrators argue that the solution for addressing stability and controlling risk in the financial industry is a good corporate governance mechanism (John, De-Masi, and Paci, 2016). Nevertheless, there exists a split decision on the subject, for some experts as financial stabilizers and for others as a source of instability now view as corporate governance. Corporate governance has two standpoints; country-level and firm-level basis. With the country-level governance, it covers regulations - such as listing requirements - that govern equity investments in public-listed firms. Firm-level corporate governance covers the defense of minority shareholders, disclosure provisions, and practices, the functions and structure of the board, and compensation structures. About the banking sector stability, the increment of the firm's value is the absolute aim of the shareholders, which serves as a motivation for management executives to venture into more risky businesses and shaking up the stability of the banking system (Ferrarini, 2017). The core schema of corporate governance is exercising control over managers so that the managers act in the interest of the shareholders. The agency theory was birthed out of corporate governance. Corporate governance bank stability relationship is not a new subject. It has been in existence for centuries evolving form a small idea to a major topic of consideration in the field of finance and governance.

\subsection{Purpose of the Research}

Despite the large literature in the field of corporate governance only few papers have focused on the governance of financial institutions. The general objective of this research is to study the relationship between corporate governance and financial stability issues of universal banks in Ghana. The specific objectives are to calculate the risk of universal banks via Z-score and other methodologies and study the 
influence corporate governance variables have on the stability of banks. There are very few studies or research works conducted to look at the relationship between banks' stability and the corporate governance in Ghana. Therefore, this research examines the stability issues that could threaten entire financial institutions and or cause systematic risk. Different from the cross-country studies, this study will focus on the country-level data of the Ghanaian banking industry. We would be observing degree and significance level of the econometric values, to determine whether financial stability objectives should be force on financial institutions in developing countries (OECD, 2004). The paper would also look at how classical issues of corporate governance such as the size of the board, board independence, executive compensation, board committee, among others factors affects the financial stability of banks.

\section{Literature Review and Research Hypotheses}

This section checks on prior literature on corporate governance and its' relationship with bank financial stability. We would also formulate, defend or expand our hypotheses. We present arguments that justify the expected relationship between the characteristics of the corporate governance and the financial stability of banks.

\subsection{Corporate Governance Defined}

The Ghanaian Securities and Exchange Commission described corporate governance in 2002 as the manner in which corporate figures are cared for and operated. The OECD (1999) further defined it as the system by which business corporations are directed and controlled (OECD, 1999). It postulates the circulation rights and responsibilities amongst dissimilar contributors in a corporation, such as the board, managers, shareholders and other stakeholders while spelling out the rules and procedure for making decisions on corporate affairs (PricewaterhouseCoopers, 2013). By doing this, corporate governance provides the structure over which the purposes are fixed and the means of accomplishing these objectives and performances monitoring.

The Bank of Ghana, defines bank corporate governance as the manner in which, business affairs of a regulated financial institution is governed by its board and senior management including how its strategy and objectives are set, its risk tolerance are determined, its day-to-day business is operated, interests of depositors are protected and shareholders obligations are met taking into account the interests of other recognized stakeholders, and aligning corporate activities and behavior with the expectation that, it will operate in a safe and sound manner with integrity and in compliance with applicable laws and regulations (PricewaterhouseCoopers, 2013). In simpler terms, corporate governance (CG) refers to the structures and processes for the direction and control of companies. Corporate governance disquiets itself 
with the relationships among the management, board of directors, controlling shareholders, minority shareholders and other stakeholders.

\subsection{Banking versus Non-Banking Financial Institutions}

Lee (2016) wonders whether CG for banking institutions, i.e., banks and bank holding companies, is (or should be) different from CG for other corporations (Heremans, 2007). Before this, Heremans (2007) had compered financial firms to non-financial firms and suggested that, corporate governance models and the functioning of the board of directors in these two fields should be designed differently. His reason was because bank serves several conflicting parties of interests from equity holders, to borrowers or depositors and good governance is important for balancing their interests. Besides the above reasons, the bank regulatory authorities seems to have other augment confirming the uniqueness of corporate governance. The banking institutions has a special credit and liquidity functions leading to a highly regulated environment for banking institutions, which has directly affected their governance processes.

\subsubsection{Corporate Governance Codes in the banking sector of Ghana}

Even before the 2008 global credit crunch, other belated economic events comprising the 1997 Asian Financial Crisis, the Wall Street crash of 1929, and the 1929-1939 great depression drew academics ' attention on corporate governance as it culminated into bank failures and worldwide economic crises (Heremans, 2007; Radelet, Sachs, Cooper, and Bosworth, 1998). History has archived firm level failures that happened because of poor corporate management. In Ghana some key examples includes Bank for Housing and Construction (collapsed in 2000) and the Cooperative Bank Ghana (collapsed in 2000), others are Unibank Ghana Ltd, UT bank limited, The Royal Bank limited, Beige Bank, Sovereign Bank, and Construction Bank Ghana limited (all folding-up in 2018) (Aryeetey and Fosu, 2003; Ayagre, Appiah-Gyamerah, and Nartey, 2014). For Investment banks Gold Coast securities (2019), DKM finance (2016) and Menz Gold Investment (2019) failing all thanks to weak governance systems and structures. Majority of the aforementioned firms had huge non-performing loans, inadequate capital reserves and poor corporate governance practices.

Disclosures and compliance with corporate governance codes of best practices by countries have become indispensable because foreign investors rely upon the financial reports of companies before having mammoth economic and financial investments commitments with them (Amartey, Yu, and Chukwu-lobelu, 2019). This practice helps developing economies and struggling institutions to model their own corporate strategic plans. One of the sectors that has seen steady development in corporate governance practices is the banking sector.

Companies“ Act, 1963 (Act 179) of Ghana is the principal legislation affecting the governance of listed companies (Code, 1963). The Companies ' Act includes general 
provisions relating to the organizational framework of all companies, both public and private, as well as special provisions for public companies only, relating to invitations to the public for the acquisition or disposal of listed securities, standards for financial reporting, procedures for appointing directors, etc. (Ghartey, 2019). Apart from the Companies" Act, other relevant legislation that affects the governance of listed companies includes the Securities Industry Act, 2016 (Act 929) and the Securities and Exchange Commission Regulations, 2003 (LI 1728), which regulate public invitations for and trading in listed securities, as well as disclosure obligations and financial reporting standards for listed companies. Considering, the 2002 corporate governance code by the SEC, many codes of best practices have originated while there have been calls for a solitary code by various regulators and stakeholders (Ghana, 2016).

\subsection{Financial Stability}

Headquartered in Basel, Switzerland, the financial stability board (FSB) was built up in 2009 after 2008 financial crisis and has taken a key portion in empowering the change of widespread money related control and supervision (Mülbert, 2009). The FSB has territorial/regional Consultative Groups (RCGs) - one each for North America, South America, Asia, the Commonwealth of Free States, Europe, Centre East and North Africa, and the Sub-Saharan Africa locale - to extend and formalize the FSB's outreach exercises past the membership of the G20. The RCGs provide a structured mechanism that promotes interactions between the FSB members and non-members regarding the board's initiatives and implementation of international financial policy.

Ghana has its own patterns when it comes to banking sector stability. Banking System stability is steady state in which the financial system performs its key economic capacities, such as designating assets and spreading risk as well as settling. Banking instability is related to banking sector difficulties that do not result in a systemic crisis. Empirical literature on bank financial stability makes it clear that, several macroeconomic determinants have been emphasized as significantly related to a bank's risk (YuSheng and Ibrahim, 2019). However, Spierdijk and Shaffer (2017) found no significant relationship between banking concentration and banking stability both at bank-level and country level (Ijtsma, Spierdijk, and Shaffer, 2017). Allen and Wood (2005) contributed to the field of financial stability by developing the conceptual framework within which financial stability can be characterized (Allen and Wood, 2005). They focused the significance of the measurability of money related soundness. Given the uncertainty related with characterizing financial stability, most authors associated the loss of stability with over the top risk. More to that, Ozili's (2018), stated that banking efficiency, foreign bank presence, banking concentration, measure of managing an account division, government viability, political soundness, administrative quality, financial specialist 
security, debasement control and unemployment levels are noteworthy determinants of managing banks' steadiness in Africa (Ozili, 2018).

Berger and DeYoung (1997) by implication suggests that efficient African banks are better at managing their credit risk which manifests via lower non-performing loans (NPLs), thus improving banking stability (Berger and DeYoung, 1997). Chow and Fung 2013 discovered that during the periods of prosperity, banks are more willing to lend, thus moderately control the risk (Chow and Fung, 2013). According to Jokipii and Monnin (2013), unstable banking sector increases uncertainty about future output growth (Jokipii and Monnin, 2013). Boateng et al. (2015) find a negative relationship between unemployment levels and bank stability (Boateng, Huang, and Kufuor, 2015). Thus, the higher the unemployment rate the higher the NPL rate of Banks and the lower the deposit/investment level causing instabilities within the financial sector.

\subsection{Bank's Board Structure and Financial Stability}

The board structure consist of the board size, board independence and board members affiliations. The responsibility of the board of directors includes internal governance system, delivering the main directions of the financing and investment, monitoring, management, and determining the compensation structure.

\subsubsection{Board Size and Bank Financial Stability}

The board is an essential governance entity, it employs and or layoff the top management at the appropriate time. In addition, the board executes all compensation schemes, ratification of financial decisions influencing corporate risk taking. Board size can be defined as the number of directors on the board. Solving the issues between shareholders and executives calls for the presence of the board of directors. From literature, the size of the board of large banks, particularly banks with many affiliates, has their board size being organizationally complex. Inferring that banks with more holdings demands more board representatives to observe activities of directors.

According to the agency theory, limiting board size to a particular level is generally believed to improving financial performance. Previous studies found positive effects of larger board size on the performance of firms. The ineffectiveness resulting from larger board are attributed to communication barrier when there are too many people involved in the decision-making process therefore, Apriliyanti and Randøy (2019) suggested that the number of BoD should be limited to ten (Apriliyanti and Randøy, 2019). Guest (2019) found out that smaller boards produce stringer returns, have stronger oversight, always more favorable (Guest, 2019). Australian Institute of Company Directors indicated that large listed companies should have 8 to 12 directors, medium-sized listed companies 6 to 8 directors and small listed companies 4 to 6 directors (Dias, Rodrigues, Craig, and Neves, 2019). The debate whether 
smaller groups of board directors are more effective than large board members arises. Hence, we hypothesized that:

Hypothesis 1.a (H1.a): Board size is positively related to bank stability. Hypothesis 1.b(H1.b): Board size is negatively related to bank stability.

\subsubsection{Board Independence and Financial Stability}

The main role of independent directors is to protect the interests of minority shareholders against any potential acquisition and to prohibit a system of excessive executive compensation for majority shareholders. For instance, Masulis and Zhang, (2019) show that an independent board decreases the cost of financing for companies . Karkowska, and Acedański (2019) insist that independent members lower a firm's idiosyncratic risk and increase its ratings. Previous studies emphasize that the independence of the members of the board of directors promotes better banking governance and, therefore, stability. By the principles of corporate governance of Ghana, independent directors are important for banks as they provide incentive compensation to managers (Akhigbe and Martin, 2006; Cornett, McNutt, and Tehranian, 2009). Battaglia and Gallo (2017) find that the number of independent directors is relevant to the probability of bank insolvency, using a sample of the largest publicly traded commercial banks, bank holding companies, and holding companies headquartered in the European Union over 2006-2010. Wang and Hsu (2013) find no support for the proposition that the presence of independent directors is negatively correlated with bank risk.

However, Anderson and Bizjak (2003) note that greater board independence does not generate pay-performance sensitivity and Subrahmanyam et al. (1997) show a negative relationship between returns and the proportion of a bank's independent director. According to Adibin et al. (2011) board independence is found to be associated with performance, though in the opposite direction. The direction of influence suggests that having too many independent directors (i.e., non-executive) might slow down the business as they might have a lack of detailed knowledge about the company's business, and are more concerned about their gatekeeper role. Therefore, we set a hypothesis as:

Hypothesis 2.a (H2.a): Board independence is positively linked to financial stability. Hypothesis 2.b (H2.b):Board independence is negatively linked to financial stability.

\subsubsection{Board Members' Affiliation and Financial Stability}

Affiliated directors is "board of directors" member who is not a current employee, but who may be either a retired employee or one who does business with the organization on which they serve as a member. They are an individual who is in a position to influence the actions of the corporation (Klein, 1998). 
Research on the board structure focuses also on the participation of externally affiliated members of the board. The empirical findings on the affiliation of the board in terms of inside and outside directors are inconsistent as regards the relationship between affiliation of board and bank stability (Lin, Yeh, and Yang, 2014). It is difficult to apply the board affiliation mechanisms directly to analyses on a bank's financial stability. This is more prominent in the banking sector, where affiliated board members are engaged for control. Even though foreign director participation contributes to better performance in the banking sector by bringing new techniques and skills. Masulis et al. (2012) found out that keeping too many foreign directors lead to a lower return on assets. Jiraporn et al. (2009) emphasize that directors who serve on a few board committees are more likely to be absent from board meetings. Fich and Shivdasani (2006) further find that boards with a majority of affiliated directors represent weaker corporate governance. These revelation cement the fact that there is a strong linkage between financial stability and affiliations of board members leading to our hypothesis as:

Hypothesis 3.a (H3.a). There is a significant relationship between banks' financial stability and board member's affiliation.

Hypothesis 3.b (H3.b) There is no significant relationship between banks' financial stability and board member's affiliation.

\subsection{Board Quality (experience-age, education, and gender diversity) and Banks' Financial Stability}

Board features are another vital aspect that may affect the stability of a firm. Board quality includes experience, background, and skills, and the role of these attributes in bank risk.

\subsubsection{Board Members' Educational Qualification and Financial Stability}

According Christiansen (2011) board members with higher education increases participation in financial decisions. Further, Darmadi, (2013), states that educational qualification may be a proxy for intelligence, where directors that are more intelligent are expected to be better than their peers. The identification and measurement of such capabilities are difficult and costly, observable and objective measures such as educational qualification need to be considered in hiring board members. Top managers of the firm are hired probably because of their superior ability, which their employers believe they obtain from higher education. The research hypothesis is as follows:

Hypothesis 4.a (H4.a): Board of directors' educational qualification is positively linked to bank financial stability. Hypothesis 4.b (H4.b): Board of directors' educational qualification is negatively linked to bank financial stability.

\subsubsection{Board Members' Financial Experience and Financial Stability}


Financial experience of board members means their past employment experience in finance or accounting, requisite professional certification in accounting, or any other comparable experience or background they have gain which results in the individual's financial sophistication, including or having been a chief executive officer, chief financial officer or other senior officer with financial oversight responsibilities. An experienced bank board member has the capacity to identify potential risks and ensure financial stability or prevent financial instability/system risk. Board experience became inescapable, after the financial crisis of 2008, where regulators declared that the board of directors should include experienced and more educated members (Bolton, Cecchetti, Danthine, and Vives, 2019).

However, as far as Europe and Sub-Sahara Africa it concerns, empirical findings indicate that bank directors still do not have extensive relevant experience. Hau and Thum (2009) analyzing a dataset of 29 German banks over the period of 2007-2008, find that directors' financial expertise has a positive impact on the profitability of banks (Hau and Thum, 2009). A more experienced board can identify risks that will affect the financial stability and, hence, can advise managers how to handle these risks to avoid losses. Beltratti and Stulz (2012) argue that banks less experience board members are likely to experience financial crisis since these banks with more favorable shareholder advice were associated with higher risk-taking and losses larger stocks during the crisis.

Another finding made by Aebi et al. (2012) examining a sample of American banks during the 2007-2008 crisis period, note that a high percentage of experienced administrators is negatively linked to bank performance measured by stock market returns. One possible explanation is that, in many cases, the bank's board of directors lacked sufficient financial expertise. Although divergent pops-out when researching the board members experience and banks' stability we have established a linkage via review of literature, based on that our hypothesis is:

Hypothesis 5.a (H4.a): The experience of board members is positively related to banks' financial stability

Hypothesis 5.b (H4.b): The experience of board members is negatively related to banks' financial stability.

\subsubsection{Age and Risk-taking}

According to Grable et al. (2009), older people are usually more tolerant towards dangers than younger people. One possible explanation for this result is that older directors have more experience and are therefore able to recognize and avoid dangerous situations. In the same line, according to the theoretical study of Gervais and Odean (2001) it is mentioned that the lack of experience in young people combined with excessive self-confidence could lead to excessive risk-taking. 
In addition, Felicio et al. (2018) analyzing a sample of European banks for the period 1996-2010, find that the age of directors reduces the overall risk of banks. This means that older managerial age is associated with less risk-taking, which seems to suggest that older directors are not inclined to take risky decisions due to their financial experience.

On the contrary, older members of the board may not have the proper energy and incentives to actively monitor managers, thereby increasing agency problems (Fernandes, Farinha, Martins, and Mateus, 2017). According to the agency theory, the main responsibility of the board is to act on behalf of the shareholders through the improvement of monitoring and controlling management. However, this monitoring role of the board can only be fulfilled when it is combined with highquality and impartial advice. For instance, Lehman Brothers was criticized for having $50 \%$ of its board members older than 70 years and hence, they were less familiar with complex financial products such as securitization of mortgage securities and credit default swaps (Poswal, 2012). Regarding the different empirical results mentioned above, we expect that:

Hypothesis 6.a (H6.a) Age of directors is positively related to financial stability. Hypothesis $6 . b$ (H6.b) Age of directors is negatively related to financial stability.

\subsubsection{Board Gender Diversity and Financial Stability}

Women are under-represented at all levels of the global financial system from depositors to borrowers, including board members of banks and regulators. Granting that women are disenfranchise in some cultures, statistically, women made up $40 \%$ of depositors and borrowers worldwide. For example, 51\% of borrowers in Brazil are women, compared to only $7 \%$ in Pakistan. Factually, women and men bring different skills and perspectives to the world of work, including a distinct approach to risk and collaboration. Research has also shown that companies see better financial results when the composition of their boards of directors is more balanced between men and women.

Although gender diversity and performance gender diversity has received increased attention in recent years. Women's participation on a board of directors remains a challenge in Europe, the United States and Africa despite the indisputable fact that the diversity of boards of directors is considered necessary for the profitability of banks. It is unfortunately mentioned that today, women still face many obstacles in their attempt to pursue their profession and professional careers (ECDG, 2011).

García-Meca et al. (2015) using different bank performance measurement concluded that the presence of women on boards has a positive effect on bank performance. However, the results of Belhaj and Mateus (2016) indicates that during the financial crisis from 2007 to 2008 specifically, the participation of women on the board of directors of European banks does not affect the profitability of banks in times of crisis. 
New study findings reveals that better inclusion of women among financial services users, providers and regulators has benefits beyond reducing gender inequalities. A smaller gap between men and women would be beneficial for the stability of the banking system and economic growth. It would also help establish more effective monetary and fiscal policies. It is surprising that no study has yet analyzed the macroeconomic impact of this microeconomic data so we develop a hypothesis that:

Hypothesis 7.a (H7.a): A high percentage of female directors is positively linked to banks' financial stability.

Hypothesis 7.b (H7.a): A high percentage of female directors is negatively linked to banks' financial stability.

\subsection{Board Activities and Financial Stability}

\subsubsection{CEO Duality}

CEO duality refers to the situation when the CEO also holds the position of the chairperson of the board. Corporate governance is based on principles such as conducting the business with all integrity and fairness, being transparent with regard to all transactions, making all the necessary disclosures and decisions, complying with all the laws of the land, accountability and responsibility towards the stakeholders and commitment to conducting business in an ethical manner. The related hypothesis is as follows:

Hypothesis 8.a (H8.a): There is statistically significant relationship between CEO duality and financial stability.

Hypothesis 8b. (H8.b): There is no statistically significant relationship between CEO duality and financial stability.

\subsubsection{Board Audit Committee}

Velte (2017) opines that the composition and resourcefulness of audit committee play a very important role in ensuring adequate corporate governance quality in the interest of investors and owners of the business. Sarbanes-Oxley Act 2002 as cited by Velte stated that publicly quoted companies must implement an Audit Committee which are financial and independent experts which tends to separate executive and non-executive directors within the board. Audit Committee implementation is to drive professionalism and enhance corporate governance quality. The Act framework states that the mentoring functions of Audit Committee covers financial reporting quality, internal audit quality and external audit quality, which all will translate into good firm performance. The research hypothesis is as follows:

Hypothesis 9.a (H9.a): There is statistically significant relationship between board audit committee activities and financial stability.

Hypothesis 9.b (H9.b): There is no statistically significant relationship between board audit committee and financial stability. 


\subsubsection{Executive Compensation and Financial Stability}

Director's pay is very important in recruiting and retaining highly qualified Directors. It is also symbolically important as a representation of the company's attitudes towards corporate governance. There has been a massive shift in how outside Board Directors have been paid over the past 20 years. This has largely been fueled by changes in corporate governance practices over time. Overall, the shift has been away from paying directors like executives and towards paying outside experts for their time and contributions during their term of service.

We anticipate further changes over the next 2 decades as corporate governance continues to evolve. From the last two decades, directors were commonly eligible benefits programs and pensions. They were awarded equity in the form of stock option grants (also used for executives), and director awards were expressed as a number of shares rather than a grant value. In addition, many companies did not differentiate pay for Committee service and lead director roles and Director stock ownership guidelines were absent. Director's pay is very important in recruiting and retaining highly qualified Directors. It is also symbolically important as a representation of the company's attitudes towards corporate governance. This is in line with the observation that the ownership structure has an influence on internal mechanisms of corporate governance (Agyemang, Aboagye, and Ahali, 2013). The research hypothesis is as follows:

Hypothesis 10.a (H10.a) Executive compensation influences banks' financial stability.

Hypothesis $10 . b$ (H10.b) Executive compensation does not influences banks' financial stability.

\section{Research Design and Methodology}

Our initial sample comprised all local and foreign banks both listed and non-listed. The inclusion criteria for our study sample were: (i) having a financial and corporate governance (CG) data during the seven-year period of 2007-2019, (ii) having applied these criteria in pectice, we obtained a balanced study sample of 24 banks. As dependent variables three indicators are used to proxy for Bank's Financial Stability (BFS).

1. Credit risk (the ratio of non-performing assets to total loans (NPA).

Note: Non-performing assets reflect loans that are at least 90 days in default or appear on scheduled payments of principal or interest (Grove, Patelli, Victoravich, ans $\mathrm{Xu}, 2011)$. Hence, NPA indicates a bank's credit quality.

2. Insolvency risk ( $\mathrm{Z}-\mathrm{SCORE}) \mathrm{ZSCORE}=(\mathrm{ROA}+\mathrm{CAR}) / \sigma(\mathrm{ROA})$.

Note: Where ROA represents earnings divided by assets, CAR represents the capital-asset ratio, and $\sigma(\mathrm{ROA})$ represents the standard deviation of ROA. Z-score is a well-established measure for the probability that negative bank returns would force it to default or bankrupt (Bhagat, Bolton, and Lu, 2015). Accordingly, a ZSCORE with a high value indicates that the bank 
has sufficient profit to cover its debt liability and, hence, has a lower probability to default or bankrupt (Bai and Elyasiani, 2013).

3. Basel Tier 1 capital ratio (TIER-1), which indicates bank adherence to the bank's regulatory capital ratio or, in other words, the bank's prudence in maintaining adequate capital, as the third proxy for BFS. Capital levels are associated with bank willingness to undertake riskier activities (Berger et al., 2009) and could have significant impacts on attracting current and potential investors (Beck, Chen, Lin, and Song, 2016).

For Corporate Governance we employed nine corporate governance variables analyzed in the previous section, that are likely to influence bank financial stability such as: board size (BS), board independency (INDEP), gender diversity (FEMALE), age (AGE), board financial experience (EXPER), compensation (compensation and wealth: COM) and audit committee (ACOM), board education (BEDU), CEO duality. The first three indicators are related to the board structure while the next five describe the board quality and the final two represent board activities.

For control variables the first is bank size (LNTA), which is calculated as the natural logarithm of total assets (Fernandes et al. 2017b). The use of the logarithm eliminates the outliers observed in the sample used, as there are banking institutions with very high total assets and others with very low. The next variable refers to the leverage of banks (LEVEGARE) and is calculated as the ratio of total debt to total assets. It is used to capture fluctuations in the capital structure of banks (Pathan, 2009). The average age of banks is calculated by summing the banks' age over the number of banks on board. Bank age is the last control variable of our equation.

\subsection{Empirical Model and Methodology}

\subsubsection{Fixed Effects Model}

Our sample is a mixture of time series and cross-sectional analysis and as a consequence the most efficient tool to use is panel data analysis (De Andres and Vallelado, 2008). The advantage of this method is that it takes into account the heterogeneity, which is the specific characteristic of each bank, such as the quality of management, business activity among others. The first econometric method we apply to control the impact of bank's governance characteristics on bank financial stability is the Fixed-Effects model. When the unobserved effect is correlated with independent variables, then this method gives unbiased estimators in contrast with Pooled OLS method which produces biased and inconsistent estimators.

Bank Financial Stability (BFS) model:

$$
\begin{aligned}
& B F S_{i, t}=\beta_{0}+\beta_{1} B S_{i, t}+\beta_{2} A G E_{i t}+\beta_{3} E_{X P E_{i t}}+\beta_{4} I N D E P_{i, t}+\beta_{5} F E M_{i, t}+\beta_{6} B C O M_{i, t}+\beta_{7} A C O M_{i, t} \\
& +\beta_{8} B_{E D U} U_{i, t}+\beta_{11} A F F L_{i, t}+\beta_{9} C E O D_{i t}+\beta_{10} L N T A_{i}+\beta_{12} \text { BANKS }_{i, t}+\beta_{13} L E V_{i, t}+U_{i} \\
& +\varepsilon_{i} \quad(1)
\end{aligned}
$$


Where BFS denote bank's financial stability for bank $i, t$ the time-period, $\beta$ the parameters to be estimated, $\ln$ the natural logarithmic, $u$ the unobserved fixed-effect for bank $i$ and $\varepsilon$ the remaining disturbance term.

\subsubsection{Endogeneity Issues and Two-step System GMM}

To address the endogeneity problem in corporate governance literature, we use the two-step system estimator approach, proposed by Arellano and Bover (1995) and Blundell and Bond (1998). This estimator involves the use of dynamic effect by adding a lagged dependent variable to the explanatory variable. Moreover, by applying the two-step system GMM, we can build instruments for endogenous variables. More precisely, to treat all potentially endogenous variables, we use their past values as their respective instruments (Vallascas and Hagendorff, 2013). To test the validity of the multiple lags as an instrument, we calculate the Hansen/Sargan test (Pathan and Faff, 2013; Andres and Vallelado, 2008). The $A R(1)$ and $A R(2)$ measure first and second degree serial correlation. The residuals of the first differences $A R(1)$ may be correlated but there should be no correlation in the second differences $A R(2)$ (Cameron and Trivedi, 2009).

Bank Financial Stability model:

$$
\begin{aligned}
& B F S_{i, t}=\beta_{0}+\beta_{1} B F S_{i, t-1}+\beta_{1} B S_{i, t}+\beta_{2} A G E_{i t}+\beta_{3} E X P E R_{i t}+\beta_{4} I N D E P_{i t}+\beta_{5} F E M_{i, t}+\beta_{6} B C O M_{i, t} \\
& +\beta_{7} A C O M_{i, t}+\beta_{11} A F F L_{i, t}+\beta_{8} B E D U_{i, t}+\beta_{9} C E O D_{i t}+\beta_{10} L N T A_{i}+\beta_{12} B A N K S_{i, t} \\
& +\beta_{13} L E V_{i t}+U_{i}+\varepsilon_{i}
\end{aligned}
$$

Where $B F S$ denote financial stability for bank $i, t$ the time period, $\ln$ the natural logarithmic, $\beta$ the parameters to be estimated, $u$ the unobserved fixed-effect for bank $\boldsymbol{i}$ and $\boldsymbol{\varepsilon}$ the remaining disturbance term.

Table 1 summarizes the definitions of the variables used in this study. More precisely, the first group concerns the dependent variables which is bank's financial stability. Moving to the second group, which represents the definitions of bank governance variables that are board size, age of directors, financial experience, percentage of independent directors, proportion of female directors, audit committee, board education compensation of directors. The third group, of Table 1 below make available the definitions of control variables (bank size, bank age and leverage).

\section{Empirical Results}

\subsection{Descriptive Statistics}

Regarding risk measures financial stability, the average age of directors (age diversity) is 57.25 with a minimum of 35 and a maximum of 72.37 which is similar to 2004-2016 European banks research by Mavrakana and Psillaki, (2019). Regarding the variable financial experience, Table 2 demonstrates that directors 
have on average 14.77 years of bank experience with a minimum of 1 year and a maximum of 26.2 years proportion of independent directors varies between $10 \%$ and $80 \%$ with a mean of $40 \%$. Our findings are in line with Belhaj and Mateus (2016), which show that the number of independent directors in European banks fluctuates from $13.79 \%$ to $96.30 \%$.

The mean percentage of female directors are $28 \%$ with a minimum value of $0 \%$ and a maximum value of 57.14\%. According to the African Development Bank 2015 report, the mean female directors' ratio in Africa is 14.4\% (Coburn, Restivo, and Shandra, 2015). Similarly, DeCabo et al. (2012) indicate that the average of women in European banks is only 7\%. With regards to the directors' educational background, Table 2 informs that on the average $84 \%$ of the board directors have obtained formal education related to business and governance. The average number of audit committee members is 4 with a minimum of 2 and a maximum of 7 .

Panel C of Table 2 presents the descriptive statistics of the control variables considered in our study. The banks in our sample have an average asset size of $\$$ 14.32 billion. We use the natural logarithm of total assets to eliminate the effect of outliers on our results. Banks are highly leveraged, the mean ratio of leverage is $83.66 \%$ while the maximum value is $99.04 \%$. The average of bank age ratio reaches at 32.25 years while the minimum value is one year.

\subsection{Empirical Results Based on the Fixed-Effects Model}

Table 3 reports the Fixed-Effects estimation results on equation (1) for banks' financial stabilitiy as the dependent variable. The effect of board size on finance stability is positive and significant at $10 \%$ level only for return on Credit Risk (NPL ratio), rendering support to hypothesis H1.a. The coefficient shows that, all other things being equal a percentage increase in the size of board of directors would improve the banks' credit risk score by $9 \%$. Our results are consistent with previous studies, such as those of Aebi et al. (2012) and Andres and Vallelado (2008), which argue that a large number of directors on boards may contribute positively to decision-making process and, hence, improve the performance of banks.

However, the effect of board size is not significant regardless for other two financial stability measures Z-score and Tier capital ratio. Its impact on Tier 1 capital suggest that increasing the number of board numbers at the time where the bank has adequate capital can harm the organization. Also, the impact of affiliated directors, which is measured by the percentage of formal employees or formal clients on the board, is negative and significant at 5\% level only for Z-Score measure and Tier 1 capital ratio. Our results indicate that higher number of affiliated directors contributes to financial destabilization. However, the insignificant relationship between the board members affiliation and NPLs measures is consistent with Fahlenbrach and Stulz (2011). Considering this we reject H3.a and accept H3.b. 
Table 1. Variables Description Table

\begin{tabular}{|c|c|c|c|}
\hline & Variables & Definitions & $\begin{array}{l}\text { Data } \\
\text { Base }\end{array}$ \\
\hline \multicolumn{4}{|c|}{ Panel A dependent Variable } \\
\hline Insolvency Risk & Z-score & $\begin{array}{l}\text { The natural logarithm of ( }(R O A+C A R) / \sigma(R O A)) \text {, where } \\
\text { ROA represents the retum on assets which is calculated as } \\
\text { the ratio of net income over assets, CAR represents the } \\
\text { capital-zaset ratio, and } \sigma(R O A) \text { represents the standard } \\
\text { deviation of ROA. }\end{array}$ & $\begin{array}{l}\text { Bank of } \\
\text { Ghana }\end{array}$ \\
\hline Credit Risk & NPA & $\begin{array}{l}\text { Accounting-based measure of asset quality, which equals } \\
\text { to non-performing assets over total loans. Nonperforming } \\
\text { assets is the classification for loans that are in default or are } \\
\text { in arrears on scheculed payments of principal or interest }\end{array}$ & $\begin{array}{l}\text { Bank of } \\
\text { Ghana }\end{array}$ \\
\hline $\begin{array}{l}\text { Tier } \quad \text { 1-capital } \\
\text { ratio }\end{array}$ & Tier l-capital ratio & $\begin{array}{l}\text { The shareholder funds plus perpetual noncumulative } \\
\text { preference shares as a percentage of risk-weighted assets } \\
\text { and off balance sheet risks measured under the Basel rules. }\end{array}$ & $\begin{array}{l}\text { Bank of } \\
\text { Ghana }\end{array}$ \\
\hline \multicolumn{4}{|c|}{ Panel B: Bank Governance Variables } \\
\hline BS & Board Sizes & $\begin{array}{l}\text { The number of directors sitting on the board/ the sum of the } \\
\text { directors within a board (errecutive and supervisory) }\end{array}$ & BoardEn \\
\hline AFFL & $\begin{array}{ll}\text { Bourd } & \text { Member's } \\
\text { Affiliation } & \end{array}$ & $\begin{array}{l}\text { Number of board members the have been an employee of } \\
\text { the orgainigation before. }\end{array}$ & BoardEn \\
\hline INDEP & Independent directors & $\begin{array}{l}\text { Ratio of the number of independent non-executive directors } \\
\text { on the board to the total number of directors on the } \\
\text { board. }\end{array}$ & BoardE $\bar{\pi}$ \\
\hline EXPE & Financial experience & $\begin{array}{l}\text { The average number of financial experience relevant either } \\
\text { on the supervisory or executive board on which the director } \\
\text { gits. }\end{array}$ & BoardEn \\
\hline $\mathrm{AGE}$ & Age of directors & The average age of the directors of the board & BoardE $\bar{n}$ \\
\hline BEDU & Educational background & $\begin{array}{l}\text { Ratio of the number of directors who hold accounting. } \\
\text { finance, and/or banking certificate to the total number of } \\
\text { directors on the board. }\end{array}$ & BoardEs \\
\hline COM & Compensation & the sum of salary and bonus & BoardE $\Omega$ \\
\hline FEM & Female directors & The percentage of directors on the board who are female & BoardEn \\
\hline CEOD & CEO duality & Number of CEOs who are also board members & BoardEn \\
\hline ACOM & Audit committee & $\begin{array}{l}\text { Number of directors on the audit committee number of } \\
\text { times the committee meet }\end{array}$ & BoardEn \\
\hline \multicolumn{4}{|c|}{ Panel C: Control Variables } \\
\hline LNTA & Bank Size & The natural logarithm of total assets & $\begin{array}{l}\text { Bank of } \\
\text { Ghana }\end{array}$ \\
\hline LEV & Leverage & $\begin{array}{l}\text { Ratio of book value of total liability to book value of total } \\
\text { zasets }\end{array}$ & $\begin{array}{l}\text { Bank of } \\
\text { Ghana }\end{array}$ \\
\hline$A B A$ & Bank Age & $\begin{array}{l}\text { The average age of banks is calculated by summing the } \\
\text { banks' age over the number of banks on board. }\end{array}$ & $\begin{array}{l}\text { Bank of } \\
\text { Ghana }\end{array}$ \\
\hline
\end{tabular}

Source: Own study.

Table 2. Descriptive statistics

\begin{tabular}{|c|c|c|c|c|c|}
\hline Variables & Observations & Mean & $\begin{array}{l}\text { Standard } \\
\text { Dev }\end{array}$ & Min & Max \\
\hline \multicolumn{6}{|c|}{ Panel A: Dependent variables } \\
\hline Z-score & 180 & 12.88 & 2.18 & 6.46 & 14.9 \\
\hline $\begin{array}{l}\text { Credit } \\
\text { Risk(NPLs) }\end{array}$ & 180 & 4.23 & 1.82 & 1.49 & 8.18 \\
\hline $\begin{array}{l}\text { Tier1-capital } \\
(\%)\end{array}$ & 180 & 21.74 & 4.86 & 12.35 & 30.58 \\
\hline
\end{tabular}


Kaodui Li, Yusheng Kong, Sampson Agyapong Atuahene,

Geoffrey Bentum-Micah, Michael Kwakye Agyapong

341

\begin{tabular}{|l|l|l|l|l|l|}
\hline BS & 180 & 8 & 2.26 & 5 & 15 \\
\hline AGE & 180 & 57.25 & 5.74 & 35 & 72.37 \\
\hline EXPR\% & 180 & 14.47 & 1.57 & 1. & 26.20 \\
\hline INDEP \% & 180 & 40 & 16.09 & 10 & 80 \\
\hline FEM\% & 180 & 28.00 & 29.81 & 0.00 & 57.14 \\
\hline EDU\% & 180 & 84 & 1.18 & 55 & 91 \\
\hline ACOM & 180 & 4.00 & 3.38 & 2 & 7 \\
\hline CEO & 180 & 1 & 0 & 1 & 1 \\
\hline AFFL & 180 & 44.10 & 8.875 & 0 & 53.33 \\
\hline $\begin{array}{l}\text { REM } \\
\text { (million } \\
\text { dollars) }\end{array}$ & 180 & 933.76 & 343.33 & 0. & \\
\hline Panel C: Control Variable & & & 852 & 3176.3 \\
\hline LNTA & 180 & 14.32544 & 0.914 & 11.5 & 16.40 \\
\hline Leverage\% & 180 & 83.66 & 3.33 & 14.40 & 99.04 \\
\hline Bank Age & 180 & 32.25 & 43.27 & 0 & 123 \\
\hline
\end{tabular}

Source: Own study.

The impact of board member educational qualifications/background, measured by the percentage number of board members who have acquired tertiary degree or professional certification in banking and finance related programs, on financial stability is negative and significant only for Z-score and Tier 1 capital ratio. This explains that diversity in-terms of educational background in important in raising of capital and achievement of net income. We take into consideration hypothesis H4.b and ignores H4.a. It is also observed from Table 3 that the experience of directors help to achieve good net income, and increases the proportion of Tier 1 capital ratio, that is why there is a robust positive linkage between number of years of experience of board directors and Z-score and Tier 1 capital. The negative signifinant recorded between directors' experience and NPLs signifies that more experienced assist in crafting good loans policies reducing credit risk in medium to long term ceterisparibus. We can therefore conclude that, experienced directors contribute to prevent bank insolvency (Fernandes et al., 2017).

Hence, we accept hypothesis H5.b. Our result is consistent with the principles established by the Committee (BCBS, 2015), which call for more experienced directors on bank boards, as it is argued that a better understanding of banking issues helps directors to oversee the management of banks more effectively. Concerning the average age of directors, it is a statistically significant relation with bank's stability indicators. Thus, we reject hypotheses H6.b and accept H6.a. Z-score thus represents a bank's distance from insolvency. A higher value of Z-score indicates greater banking stability. So, if the age of directors is positively related to Z-score it means when the directors get older the bank of which they governs becomes more grounded. 
There is insignificant relationship between the percentage of independent directors and financial stability measures which is consistent with Erkens et al. (2012) who examine a sample of European banks and they show that the proportion of independent directors have no statistically significant impact on risk-taking. The effect of female directors on bank risk-taking is negative and significant for nonperforming loans (NPL) at 10\% significant level. Our findings are supported by Muller and Lewellyn (2011) who find that a high percentage of female directors is linked with a high level of risk-taking and, hence, leads to the destabilization of banks. Our results also indicate that women do not have the appropriate experience, unlike male directors, and consequently make dangerous decisions which contribute to more credit risk and more losses for banks. Thus, we accept hypotheses H7.b. Hypothesis H8.a is accepted, for the fact that there is a significant relationship between CEO duality and bank solvency measures.

Although the results regarding the coefficient of audit committee members on financial stability indicators are mixed, however, its impact on all the stability indicators are statistically insignificant. This concludes that there is no significant statistical linkage between the number of audit committee members on the board and financial stability so, we accept H9.b. The impact of compensation, which is measured by cash and bonus, on bank financial stability is positive but insignificant. Our results indicate that higher compensation does not contributes to financial stability. For this reason we reject hypothesis 10.a, that executive compensation significantly influences bank financial stability. Thus, we therefore accept H10.b.

As it concerns the control variables, the bank size appears to be negatively and statistically significant at $1 \%$ and $5 \%$ level regardless of how financial stability is measured. One possible explanation is that the increase of portfolio diversification leads to lower risks and therefore, lower return for banks. Our findings support previous research conducted by Staikouras et al. (2007), Belhaj and Mateus (2016), among others. This does not support the "too-big-to-fail" concept (Berger et al., 2012).

The results regarding the coefficient of bank age on financial stability are mixed. However, it is statistically significant at $1 \%$ level. Relating bank's age to Z-score it simply explains that banks that have been in the system for a longer period are familiar with ways to make their company solvent. However, our findings indicate that the effect of leverage ratio on financial stability is mixed, positive for Z-Score and non-performing loans (NPL) but negative for Tier 1 capital ratio at $1 \%$ level.

Table 3. Empirical results for banks' stability based on Fixed-Effects

\begin{tabular}{|l|l|l|l|}
\hline \multicolumn{1}{|c|}{ Variables } & Z-score & $\begin{array}{l}\text { Credit } \\
\text { Risk(NPLs) }\end{array}$ & $\begin{array}{l}\text { Tier1-capital } \\
(\mathbf{\%})\end{array}$ \\
\hline Board Sizes & 0.302 & 0.0910 & -0.000346 \\
\hline Average AGE & $(0.376)$ & $\mathbf{( 0 . 0 8 0}$ *) & 0.971 \\
\hline
\end{tabular}




\begin{tabular}{|c|c|c|c|}
\hline & $(0.020 * *)$ & $\left(0.0258^{* *}\right)$ & $(0.000)^{* * *}$ \\
\hline Experience & $\begin{array}{l}0.0661 \\
(\mathbf{0 . 0 4 2 6} * *)\end{array}$ & $\begin{array}{l}-0.00298 \\
\mathbf{0 . 0 1 7} * *\end{array}$ & $\begin{array}{l}0.00311 \\
(0.187)\end{array}$ \\
\hline Independent & $\begin{array}{l}0.003 \\
(0.098)\end{array}$ & $\begin{array}{l}0.0011 \\
(0.487)\end{array}$ & $\begin{array}{l}0.00088 \\
(0.774)\end{array}$ \\
\hline CEO. Duality & $\begin{array}{l}0.08530 \\
(0.680)\end{array}$ & $\begin{array}{l}0.5264 \\
(0.056)^{*}\end{array}$ & $\begin{array}{l}0.7158 \\
(0.000) * * *\end{array}$ \\
\hline $\begin{array}{l}\text { Number of Female } \\
\text { Directors }\end{array}$ & $\begin{array}{l}-0.286 \\
(0.245)\end{array}$ & $\begin{array}{l}-0.0893 \\
(\mathbf{0 . 0 9 0 *})\end{array}$ & $\begin{array}{l}-0.0060 \\
(0.388)\end{array}$ \\
\hline EDU\% & $\begin{array}{l}-18.620 \\
(\mathbf{0 . 0 0 0} * * *)\end{array}$ & $\begin{array}{l}-.0042 \\
(0.953)\end{array}$ & $\begin{array}{l}-0.3402 \\
(\mathbf{0 . 0 0 4} * *)\end{array}$ \\
\hline ACOM & $\begin{array}{l}0.4031846 \\
(0.308)\end{array}$ & $\begin{array}{l}-0.0071 \\
(0.240)\end{array}$ & $\begin{array}{l}-0.0018 \\
0.872)\end{array}$ \\
\hline AFFL & $\begin{array}{l}-0.190 \\
(\mathbf{0 . 0 4 3} * *)\end{array}$ & $\begin{array}{l}-0.0072 \\
(0.113)\end{array}$ & $\begin{array}{l}-0.0055 \\
(\mathbf{0 . 0 3 7} * *)\end{array}$ \\
\hline REM (million dollars) & $\begin{array}{l}0.001 \\
(0.516)\end{array}$ & $\begin{array}{l}7.220 \\
0.349\end{array}$ & $\begin{array}{l}0.0001 \\
(0.478)\end{array}$ \\
\hline LNTA & $\begin{array}{l}-3.672 \\
(\mathbf{0 . 0 0 1} * * *)\end{array}$ & $\begin{array}{l}-0.0420 \\
(\mathbf{0 . 0 2 1} * *)\end{array}$ & $\begin{array}{l}-0.1668 \\
(\mathbf{0 . 0 0 0} * * *)\end{array}$ \\
\hline Leverage\% & $\begin{array}{l}1.250 \\
(\mathbf{0 . 0 0 0} * * *)\end{array}$ & $\begin{array}{l}-0.0567 \\
(0.140)\end{array}$ & $\begin{array}{l}-0.2565 \\
(\mathbf{0 . 0 0 0} * * *)\end{array}$ \\
\hline Bank Age & $\begin{array}{l}1.249 \\
(\mathbf{0 . 0 0 0} * * *)\end{array}$ & $\begin{array}{l}0.0143 \\
(\mathbf{0 . 0 0 4} * * *)\end{array}$ & $\begin{array}{l}-0.0555 \\
(\mathbf{0 . 0 0 0} * * *)\end{array}$ \\
\hline
\end{tabular}

Note: This Table reports regression results obtained via the Fixed-Effects method. The dependent variable is bank risk(RISK) which measured by Z-Score, NPL and Tier1-Capital. Definitions of all variables are provided in Table 1.

Superscripts $*, * *, * * *$ indicate statistical significance at $10 \%, 5 \%$ and $1 \%$ levels, respectively. $P$-values are reported in parentheses.

Source: Own study.

\subsection{Empirical Results Based on the Two-step System GMM Method}

The baseline regression is augmented by including the lagged dependent variable of risk measures, leading to dynamic panel data set specifications. In this specification, the lagged risk dependent variable is allowed to be correlated with unobserved heterogeneity. This suggests the use of an instrumental variable methodology to estimate the augmented baseline regression. We employ Stata's function xtabond2 (Roodman, 2009) with option collapse for the GMM-style instruments to limit instrument proliferation. This section consists of three parts. First, we summarize the baseline findings on the relationship between the bank stability measures and the corporate governance indicators. In addition, we present some additional results that are helpful in understanding the baseline findings of the study.

Contradicting the result of the fixed effect in Table 3, the dynamic panel GMM system estimation results in Table 4 shows that the result of board size (BS) is negatively related to Z-score but positively to Tier 1 capital ratio. As in 
Beltratti and Stulz, (2012) and Pathan and Faff, (2013), we note that the board of directors becomes less effective when the number of members increases. Thus, considering only the Z-score hypothesis H1.a is rejected. Also, the coefficient of board size (BS) is positively related with Credit Risk(NPLs) using both methods (fixed effect and GMM), explaining that as the board size increases, the board has more chance of including more risk lovers members and these new contribute to growing the capital/equity base of the bank. Therefore, per credit risk measure, we accept hypothesis H1.a. For the above reason, we say that the impact of board size on the three indicators of bank stability indicators is mixed.

In agreement with our results based on the Fixed-Effects method, the relationship between board age and financial stability is now significant at $1 \%$ level, except for return rendering to support hypotheses H6.a. The impact of board age on risk-taking is positive at $1 \%$ level for non-performing loans (NPL). One possible explanation is that older members lack the required energy and motivation to monitor, thereby increasing agency problems (Laeven, 2013). A significant positive relationship between the directors' age and tier 1 capital explains that older members are to rake in more funds as capital.

The effect of financial experience/expertise on bank stability is positive and significant at $1 \%$ level but only for for Z-score and Tier 1 capital, confirming hypothesis H5.a (Table 4). Furthermore, in contradiction to the results, the experience of directors has a negative impact on credit risk-taking. One possible explanation is that managers often operate in the interest of shareholders and hence led to risky decisions. Our findings are in line with Minton et al. (2011), David et al. (2010).

Moreover, the effect of independent directors (INDEP) on risk-taking is positive and statistically insignificant for only the Z-Score ratio, rendering support to hypotheses H2.a. confirming the research of Mavrakana and Psillaki (2019). It means that for a bank to be more solvent they have to get outside directors to help them with new strategic ideas.

The effect of female directors on bank stability is negative and significant at $5 \%$ level but only for credit risk falling in line with Adams and Funk's (2011) research, which concluded, that female directors are more prone to take risks than men. So, we reject H7.b. and accept H7.a. In contradiction with our previous results, the effect of female directors on bank risk-taking is negative and insignificant at all statistical levels of significance for the Z-Score ratio. This result is related to Faccio et al. (2011) findings that there is an inverse link between firm risk and female directors. The relative amount of female board members has a positive effect on the bank's insolvency risk.

Concerning the relationship between banks' financial stability and compensation, the results are not the same as on the Fixed-Effects model (Table 3). More precisely, the 
compensation of directors is negative and significant at 5\% level for Tier 1 capital, rendering support to hypothesis H10.b. One possible explanation for this result is that the increase in compensation inversely affects some elements of shareholders' fund (income surplus) on the relative performance measure, however, this is contradictory to Barro and Barro (1990) and Curi and Murgia (2018) findings. One possible explanation for our findings is that compensation is sensitive to stock market performance and, hence, directors are more willing to invest in positive net present value projects. The results regarding the impact of the board members' affiliation variable on financial stability are the same in the two-step system GMM model and Fixed Effect model. Both showed that affiliated board members have no statistically significant effect on the solvency, capital adequacy, and the credit risk issues of banks. We, therefore, accept hypothesis H3b.

According to Table 4, we find a negative and significant relationship between board education qualification (composition) and banks' financial stability, measured by credit risk (NPLs) indicator at a 10\% level of statistical significance. Thus, we reject hypothesis H4.a. One possible explanation for our findings is that if the board increases the representation of executives withholding degrees, risk-taking declines. Thus, raising the proportion of executives with first degree and more reduces risktaking (Tonello, 2011). The audit committee activities had a significant negative impact on Tier 1 capital ratio as a measure of stability, therefore, we reject H9a.a. Duality has a positive and significant impact on bank risk measures, except for the $\mathrm{Z}$ score. This suggests that duality is a key determinant for key bank risk indicators, namely Non-Performing Loans and Tier 1 capital ratio.

Table 4. Empirical results for banks' stability based on GMM

\begin{tabular}{|c|c|c|c|}
\hline Variables & Z-score & $\begin{array}{l}\text { Credit } \\
\text { Risk(NPLs) }\end{array}$ & $\begin{array}{l}\text { Tier1-capital } \\
\text { Ratio }\end{array}$ \\
\hline Z-Score $_{(t-1)}$ & $\begin{array}{l}0.36619 \\
(0.010)^{* * *}\end{array}$ & & \\
\hline $\mathbf{N P L}_{(t-1)}$ & & $\begin{array}{l}0.4420 \\
(0.000) * * *\end{array}$ & \\
\hline Tier1-Capital $(\mathrm{t}-1)$ & & & $\begin{array}{l}0.5367 \\
(0.000) * * *\end{array}$ \\
\hline Board Sizes & $\begin{array}{l}-0.38242 \\
(0.035) * * *\end{array}$ & $\begin{array}{l}0.0222 \\
(0.000) * * *\end{array}$ & $\begin{array}{l}0.0031 \\
(0.677)\end{array}$ \\
\hline Average AGE & $\begin{array}{l}0.09750 \\
(0.011) * * *\end{array}$ & $\begin{array}{l}0.3280 \\
(0.024) * *\end{array}$ & $\begin{array}{l}0.0156 \\
(0.001)^{*}\end{array}$ \\
\hline Experience & $\begin{array}{l}0.02632 \\
(0.885)\end{array}$ & $\begin{array}{l}0.0132 \\
(0.008) * * *\end{array}$ & $\begin{array}{l}0.00157 \\
(0.419)\end{array}$ \\
\hline Independent & $\begin{array}{l}0.40100 \\
(0.000) * * *\end{array}$ & $\begin{array}{l}-0.0003 \\
(0.955)\end{array}$ & $\begin{array}{l}-0.00178 \\
(0.415)\end{array}$ \\
\hline CEO. Duality & $\begin{array}{l}0.18530 \\
(0.780)\end{array}$ & $\begin{array}{l}0.4064 \\
(0.066) *\end{array}$ & $\begin{array}{l}0.9158 \\
(0.001) * * *\end{array}$ \\
\hline Number of Female Directors & -0.0806 & 0.1410 & 0.00164 \\
\hline
\end{tabular}




\begin{tabular}{|l|l|l|l|}
\hline & $(0.158)$ & $(0.021)^{* *}$ & 0.815 \\
\hline Educational & 7.2708 & -0.0418 & 0.1168 \\
Composition/qualifications & $(0.821)$ & $(0.061)^{*}$ & $(0.249)$ \\
\hline Audit Committee & 0.6616 & .03099 & -0.0251 \\
& $(0.219)$ & $(0.559)$ & $(0.015)^{* *}$ \\
\hline Affiliated Members & .08157 & -0.00006 & -0.0031 \\
& $(0.552)$ & $(0.997)$ & $(0.254)$ \\
\hline Directors' Compensation & -0.0007 & -0.00012 & 0.000011 \\
\hline LNTA (natural log of the total & $(0.588)$ & $(0.030)^{* *}$ & $(0.404)$ \\
\hline assets) & 0.17016 & 0.10057 & 0.03423 \\
\hline Leverage\% & $(0.038)^{* *}$ & $(0.008)^{*}$ & $(0.002)^{* *}$ \\
\hline Bank Age & -0.8192 & 0.85200 & -0.46060 \\
\hline Observations & $(0.000) * * *$ & $(0.0064)^{* * *}$ & $(0.000)^{* * *}$ \\
\hline AR(1) & 0.07539 & 0.0023 & -.000497 \\
\hline AR(2) & $(0.557)$ & $(0.141)$ & $(0.148)$ \\
\hline Hansen J-stat & 125 & 115 & 126 \\
\hline Number of Instruments & -1.83 & -2.16 & $-3.310 .001 * * *$ \\
\hline Number of Banks & $(0.068)^{*}$ & $(0.031)^{* *}$ & \\
\hline Note: & $0.73(0.464)$ & -1.89 & $-0.67(0.502)$ \\
\hline & & $(0.059)^{*}$ & \\
\hline & 0.0001 & $76(0.192)$ & $76.72(0.219)$ \\
\hline & 23 & 17 & 83 \\
\hline
\end{tabular}

Note: Table above reports dynamic specification of BHC risk-taking determinants. The models are estimated using GMM System and include year dummies. F-test is a test of the joint significance of reported coefficient estimates under null hypothesis. Sargan test is a test of over identifying restrictions under the null of instrument validity. $A R(1)$ and $A R(2)$ are tests for frst and second order serial correlation in residuals. $t$ statistics in parentheses.

$* p<0.10, * * p<0.05, * * * p<0.01$

Source: Own study.

The effect of size (LNTA) on bank risk-taking is positive and significant at $1 \%$ and $5 \%$ level for the Tier 1capital ratio and Z-Score respectively in line with the "toobig-to-fail" concept mentioned previously. In addition, the effect of size (LNTA) on bank risk-taking is positive and significant at $1 \%$ for Non-performing loans, this can be explained by the fact that as the asset grow, for instance, loans have a high possibility a good portion of the loan to go bad if care is not taking. Our result indicates that banks' age has no significant effect on banks stability.

According to the leverage ratio, the sign of the relationship remains constant and positive for non-performing loans (NPL) but negative for the Tier 1 capital ratio and Z-score. More, precisely, banks with higher leverage tend to decrease the Tier 1 capital ratio and to increase credit risk. One possible explanation for this result is that an increase in the non-performing loans (NPL) means that the bank does not have the necessary capital to cover its liabilities and, hence, it is led to external sources, which are linked to more leverage. 


\section{Conclusions}

As Corporate Governance is a necessary complement to regulatory and supervisory intervention, it should be approached not only from a point of view of profit maximization but also from the perspective of financial stability. In response to the regulation and guidelines set out by the Basel III framework and the world's financial stability board, financial regulators took actions to improve corporate governance practices in the banking system due to weaknesses in bank management that led to many bankruptcies.

We studied the influence of bank governance on bank stability in a sample of 23 Ghanaian commercial banks for the period from 2008 to 2019. To the best of our knowledge, this is the maiden research, which links a bank's financial stability (risktaking) with corporate governance for a West African country (Ghana). We manually collected data from banks' annual reports in the period 2008 to 2019. We explore the effect of board structures on bank risk, which is associated with regulation and complexity.

First, this research reports a robust positive relationship between board size and bank stability when we use the fixed effects estimator. With the GMM model, our results are mixed depending on the bank risk measure. The $\mathrm{Z}$-score measure gave us a negative effect between board size and bank stability. This result suggests that strong corporate governance ensuring bank stability means small boards. Next, we acknowledge a positive relationship between boards' average age, and bank stability when we use the fixed effects estimators. In the GMM model, our results were the same as that of the fixed effects, the board members' average age is statistically significant and positively related to bank stability. Also, the effect of financial experience relating to bank stability when we use the fixed effects estimator is mixed depending on the type of risk indicator. With the GMM model, the effect of financial experience on bank stability is positive and significant only for Non-performing loans measure (Elamer, Ntim, Abdou, and Pyke, 2019).

Further, using the fixed effect estimator, the effect of independent directors is insignificant to the bank's financial stability indicators (measures). However, the effect of independent directors is positive on risk-taking when we use the GMM model supporting the view that an independent board Chairman constructively challenges the CEO and strengthens governance checks and balances (Zulkafli, Amran, and Abdul Samad, 2010). The effect of female directors is negative on banks' stability when we use the fixed effects estimators but positive in the GMM model for only credit risk measures.

A controversial issue commonly debated is whether a bank CEO should also hold the title of Chairman (Larcker and Tayan 2016). The theory argues that the separation of the CEO and Chairman roles results in limited monitoring affecting the 
bank's stability so we test how CEO duality influences the risk-taking of Ghanaian banks. We realized that the effect CEO duality is significant and positive on banks' stability when we use both the fixed-effect model and GMM model for NPLs and Tier 1 capital. Dejectedly, duality is not a predictor for the Z-score, possibly, as this measure does not observe weakening earnings or capital trends.

From our empirical review, directors' educational background should make significant changes in managing and reducing bank risk exposure. The effect of the educational composition/qualifications is negative on banks' stability after we applied fixed effect and GMM models. Directors with different educational backgrounds, skills, and knowledge provide unique human capital to the board, which might reflect managers' ability and motivation to safeguard banks' investments. This explains the negative relationship between directors' educational background and bank stability for credit risk indicators.

The effect of audit committee influences is positively related to risk-taking, however statistically insignificant when we use the fixed effects estimators but negatively related (significant p-value) when we use the GMM model. The effect of directors' compensation is statistically insignificant when we use the fixed effects estimators but negatively related (significant p-value) when we use the GMM model. This result is consistent with Houston and James (1995) findings that that directors' compensation does not necessarily promote risk-taking in banking.

Overall, our results show that corporate governance variables have a significant impact on bank stability. Consistent with Elamer et al. (2018), this study presents evidence that corporate governance matters to banks' financial stability.

However, the findings are mixed regardless of measures and years. Moreover, our results have major implications for depositors, regulators, policymakers, and investors of the banking industry. The Basel Committee has issued a series of principles on corporate governance of banks and, thus, the current research essay enriches these principles that are particularly important for effective market discipline. According to the latter, issues related to the existence of corporate governance rules, transparency and the recruitment of suitable managers as members of the board of directors, require appropriate management to protect shareholder rights and ensure proper and complete disclosure of depositors and governments on the course of banking institutions and the stability of the financial system.

The limited relation between board governance controls and bank solvency we document here would help to develop a deeper understanding of bank behavior in stressful situations. We hope that our study contributes to the understanding of corporate governance in the banking sector, motivates further research to protect financial stability. 
Kaodui Li, Yusheng Kong, Sampson Agyapong Atuahene,

Geoffrey Bentum-Micah, Michael Kwakye Agyapong

\section{References:}

Abidin, S., Ahmad-Zaluki, N.A., Ilona, D. 2011. Board quality and the performance of Indonesian listed companies. Corporate Board: Role, Duties \& Composition, 7(1), 57-65.

Adams, R.B., Funk, P. 2012. Beyond the glass ceiling: Does gender matter? Management Science, 58(2), 219-235.

Aebi, V., Sabato, G., Schmid, M. 2012. Risk management, corporate governance, and bank performance in the financial crisis. Journal of Banking \& Finance, 36(12), 32133226.

Aguilera, R.V., Cuervo-Cazurra, A. 2009. Codes of good governance. Corporate governance: an international review, 17(3), 376-387.

Agyemang, O.S., Aboagye, E., Ahali, A.Y.O. 2013. Prospects and Challenges of Corporate Governance in Ghana. International Journal of Scientific and Research Publications, 87.

Akhigbe, A., Martin, A.D. 2006. Valuation impact of Sarbanes-Oxley: Evidence from disclosure and governance within the financial services industry. Journal of Banking \& Finance, 30(3), 989-1006.

Allen, W.A., Wood, G. 2005. Defining and achieving financial stability/Special Paper № 160, Cass Business School, City University.

Amartey, L.A., Yu, M., Chukwu-lobelu, O. 2019. Corporate governance in Ghana: An analysis of board accountability in Ghanaian listed banks. Journal of Financial Regulation and Compliance, 27(2), 126-140.

Apriliyanti, I.D., Randøy, T. 2019. Between politics and business: Boardroom decision making in state-owned Indonesian enterprises. Corporate governance: an international review, 27(3), 166-185.

Arellano, M., Bover, O. 1995. Another look at the instrumental variable estimation of errorcomponents models. Journal of econometrics, 68(1), 29-51.

Aryeetey, E., Fosu, A.K. 2003. Economic growth in Ghana: 1960-2000. Draft, African Economic Research Consortium, Nairobi, Kenya, 6(3), 21-34.

Ayagre, P., Appiah-Gyamerah, I., Nartey, J. 2014. The effectiveness of Internal Control Systems of banks. The case of Ghanaian banks. International Journal of Accounting and Financial Reporting, 4(2), 377.

Bai, G., Elyasiani, E. 2013. Bank stability and managerial compensation. Journal of Banking \& Finance, 37(3), 799-813.

Barro, J.R., Barro, R.J. 1990. Pay, performance, and turnover of bank CEOs. Journal of Labor Economics, 8(4), 448-481.

Battaglia, F., Gallo, A. 2017. Strong boards, ownership concentration and EU banks' systemic risk-taking: Evidence from the financial crisis. Journal of International Financial Markets, Institutions and Money, 46, 128-146.

Bcbs, B.I.S. 2010. Report and recommendations of the cross-border bank resolution group. Basel Committee on Banking Supervision.

Beck, T., Chen, T., Lin, C., Song, F.M. 2016. Financial innovation: The bright and the dark sides. Journal of Banking \& Finance, 72, 28-51.

Beltratti, A., Stulz, R.M. 2012. The credit crisis around the globe: Why did some banks perform better? Journal of financial Economics, 105(1), 1-17.

Berger, A.N., DeYoung, R. 1997. Problem loans and cost efficiency in commercial banks. Journal of Banking \& Finance, 21(6), 849-870. 
Berger, A.N., Hasan, I., Zhou, M. 2009. Bank ownership and efficiency in China: What will happen in the world's largest nation? Journal of Banking \& Finance, 33(1), 113130.

Bhagat, S., Bolton, B., Lu, J. 2015. Size, leverage, and risk-taking of financial institutions. Journal of Banking \& Finance, 59, 520-537.

Blundell, R., Bond, S.J.J. 1998. Initial conditions and moment restrictions in dynamic panel data models. 87(1), 115-143.

Boateng, A., Huang, W., Kufuor, N.K. 2015. Commercial bank ownership and performance in China. Applied Economics, 47(49), 5320-5336.

Bolton, P., Cecchetti, S., Danthine, J.P., Vives, X. 2019. Assessing a Decade of Financial Regulation. Banking Initiative, Centre for Economic Policy Research.

Chow, W.W., Fung, M.K. 2013. Financial development and growth: a clustering and causality analysis. The Journal of International Trade \& Economic Development, 22(3), 430-453.

Christensen, T.J.H. 2011. University governance reforms: potential problems of more autonomy? 62(4), 503-517.

Coburn, C., Restivo, M., Shandra, J.M. 2015. The African Development Bank and women's health: A cross-national analysis of structural adjustment and maternal mortality. Social science research, 51, 307-321.

Code, G.C. 1963. Ghana, Companies Code (Act 179). In: Act of Parliament Accra.

Cornett, M.M., McNutt, J.J., Tehranian, H. 2009. Corporate governance and earnings management at large US bank holding companies. Journal of Corporate finance, $15(4), 412-430$.

Curi, C., Murgia, M. 2018. Bank CEOs: Characteristics, Compensation Policies, and Impacts on Bank Performance. Springer.

Darmadi, S. 2013. Board members' education and firm performance: evidence from a developing economy. International Journal of Commerce \& Management, 23(2), 113.

David, P., O'Brien, J.P., Yoshikawa, T., Delios, A. 2010. Do shareholders or stakeholders appropriate the rents from corporate diversification? The influence of ownership structure. Academy of Management Journal, 53(3), 636-654.

De Andres, P., Vallelado, E. 2008. Corporate governance in banking: The role of the board of directors. Journal of Banking \& Finance, 32(12), 2570-2580.

De Cabo, R.M., Gimeno, R., Nieto, M.J. 2012. Gender diversity on European banks' boards of directors. Journal of business ethics, 109(2), 145-162.

Dias, A., Rodrigues, LL., Craig, R., Neves, M.E. 2019. Corporate social responsibility disclosure in small and medium-sized entities and large companies. Social Responsibility Journal.

Elamer, A.A., Ntim, C.G., Abdou, H.A., Pyke, C. 2019. Sharia supervisory boards, governance structures and operational risk disclosures: Evidence from Islamic banks in MENA countries. Global Finance Journal, 100488.

Elyasiani, E., Zhang, L. 2015. Bank holding company performance, risk, and "busy" board of directors. Journal of Banking \& Finance, 60, 239-251.

European Commission. Directorate-General for, C. 2011. Report on competition policy: The Commission.

Fernandes, C., Farinha, J., Martins, F.V., Mateus, C. 2017. Supervisory boards, financial crisis and bank performance: do board characteristics matter? Journal of banking regulation, 18(4), 310-337. 
Kaodui Li, Yusheng Kong, Sampson Agyapong Atuahene,

Geoffrey Bentum-Micah, Michael Kwakye Agyapong

Ferrarini, G. 2017. Understanding the role of corporate governance in financial institutions:

A research agenda. European Corporate Governance Institute (ECGI)-Law Working Paper, 347.

García-Meca, E., García-Sánchez, I.M., Martínez-Ferrero, J. 2015. Board diversity and its effects on bank performance: An international analysis. Journal of Banking \& Finance, 53, 202-214.

Ghana. 2016. List of Acts of the Republic of Ghana from 1993-2017.

Ghartey, K.N.O. 2020. Directors' duties under the 2019 Companies Act of Ghana. Commonwealth Law Bulletin, 1-21.

Grove, H., Patelli, L., Victoravich, L.M., Xu, P. 2011. Corporate governance and performance in the wake of the financial crisis: Evidence from US commercial banks. Corporate governance: an international review, 19(5), 418-436.

Guest, P.M. 2019. Does board ethnic diversity impact board monitoring outcomes? British Journal of Management, 30(1), 53-74.

Hau, H., Thum, M. 2009. Subprime crisis and board (in-) competence: private versus public banks in Germany. Economic Policy, 24(60), 701-752.

Heremans, D. 2007. Corporate governance issues for banks: a financial stability perspective. Available at SSRN 1024693.

Ijtsma, P., Spierdijk, L., Shaffer, S. 2017. The concentration-stability controversy in banking: New evidence from the EU-25. Journal of Financial Stability, 33, 273-284.

John, K., De Masi, S., Paci, A. 2016. Corporate governance in banks. Corporate governance: an international review, 24(3), 303-321.

Jokipii, T., Monnin, P. 2013. The impact of banking sector stability on the real economy. Journal of International Money and Finance, 32, 1-16.

Karkowska, R., Acedański, J. 2019. The effect of corporate board attributes on bank stability. Portuguese Economic Journal, 1-39.

Klein, A. 1998. Affiliated Directors: Puppets of Management or Effective Directors? New York University, Center for Law and Business, Working Paper, 98-010.

Kourtis, E., Kourtis, G., Curtis, P. 2019. An Integrated Financial Ratio Analysis as a Navigation Compass through the Fraudulent Reporting Conundrum: A Case Study. International Journal of Finance, Insurance and Risk Management, 9(1-2), 3-20. DOI: $10.35808 /$ ijfirm/187.

Kourtis, P.G., Kourtis, P.L., Kourtis, P.M.,Curtis, P. 2017. Fundamental Analysis, Stock Returns and High B/M Companies. International Journal of Economics and Business Administration, 5(4), 3-18. DOI: 10.35808/ijeba/139.

Lin, Y.f., Yeh, Y.M.C., Yang, F.M. 2014. Supervisory quality of board and firm performance: a perspective of board meeting attendance. Total Quality Management \& Business Excellence, 25(3-4), 264-279.

Lupu, I. 2015. The indirect relation between corporate governance and financial stability. Procedia economics and finance, 22, 538-543.

Masulis, R.W., Wang, C., Xie, F. 2012. Globalizing the boardroom-The effects of foreign directors on corporate governance and firm performance. Journal of Accounting and Economics, 53(3), 527-554.

Masulis, R.W., Zhang, E.J. 2019. How valuable are independent directors? Evidence from external distractions. Journal of Financial Economics, 132(3), 226-256.

Mavrakana, C., Psillaki, M. 2019. Do economic freedom and board structure matter for bank stability and bank performance? Retrieved from https://mpra.ub.unimuenchen.de/95709/. 
Mülbert, P.O. 2009. Corporate governance of banks after the financial crisis-theory, evidence, reforms. ECGI-Law Working Paper, 130.

OECD. 1999. The price of water: Trends in OECD countries: Organisation for Economic Co-operation and Development.

OECD. 2004. The OECD principles of corporate governance. Contaduría y Administración, 216.

Ozili, P.K. 2018. Banking stability determinants in Africa. International Journal of Managerial Finance.

Pathan, S. 2009. Strong boards, CEO power and bank risk-taking. Journal of Banking \& Finance, 33(7), 1340-1350.

Pathan, S., Faff, R. 2013. Does board structure in banks really affect their performance? Journal of Banking and Finance, 1573-1589.

Poswal, B.A. 2012. Financial innovations: role of CDOs, CDS and securitization during the US financial crisis 2007-2009. Ecorfan Journal, 3(6), 125-139.

PricewaterhouseCoopers. 2013. Ghana Banking Survey: Harnessing the SME Potential. Accra, Price Waterhouse Coopers.

Radelet, S., Sachs, J.D., Cooper, R.N., Bosworth, B.P. 1998. The East Asian financial crisis: diagnosis, remedies, prospects. Brookings papers on Economic activity, 1998(1), 190.

Tonello, M. 2011. Separation of Chair and CEO Roles, The Harvard Law School Forum on Corporate Governance and Financial Regulation.

Vallascas, F., Hagendorff, J. 2013. The risk sensitivity of capital requirements: Evidence from an international sample of large banks. Review of Finance, 17(6), 1947-1988.

Wang, T., Hsu, C. 2013. Board composition and operational risk events of financial institutions. Journal of Banking \& Finance, 37(6), 2042-2051.

YuSheng, K., Ibrahim, M. 2019. Service innovation, service delivery and customer satisfaction and loyalty in the banking sector of Ghana. International Journal of Bank Marketing.

Zulkafli, A.H., Amran, A., Abdul Samad, M.F. 2010. Board structure and firm value: a study on listed banking firms in the Asian emerging markets. International Journal of Business Governance and Ethics, 5(3), 157-177. 